\author{
Nikola Anđelić \\ E-mail: nandelic@riteh.hr \\ Vedran Mrzljak \\ E-mail: vedran.mrzljak@riteh.hr \\ Ivan Lorencin \\ E-mail: ilorencin@riteh.hr \\ Sandi Baressi Šegota \\ E-mail: sbaressisegota@riteh.hr \\ University of Rijeka, Faculty of Engineering, Vukovarska 58, 51000 Rijeka, Croatia
}

\title{
Comparison of Exergy and Various Energy Analysis Methods for a Main Marine Steam Turbine at Different Loads
}

\begin{abstract}
This paper present energy and exergy analysis of the main marine steam turbine, which is used for the commercial LNG (Liquefied Natural Gas) carrier propulsion, at four different loads. Energy analysis is performed by using four different methods. The presented analysis allows distinguishing advantages and disadvantages of all observed energy analysis methods and its comparison to exergy analysis of the same steam turbine. Each analysis is based on the measurement results obtained in main turbine exploitation conditions. Main turbine is composed of two cylinders - High Pressure Cylinder (HPC) and Low Pressure Cylinder (LPC). At low turbine loads, the dominant power producer is HPC, while at middle and high loads the dominant power producer is LPC. Energy analysis Method 1 which is based on the same principles as exergy analysis, should be avoided if the majority of turbine losses are not known. Other observed energy analysis methods can be applied in the analysis of any steam turbine, with a note that increase in ideal (isentropic) steam expansion process divisions will result with an increase in energy losses and with a decrease in energy efficiency. Energy analysis Method 2 which consist of only one ideal (isentropic) steam expansion process, for the whole turbine and at all observed loads, results with the lowest energy losses (in the range between $639.98 \mathrm{~kW}$ and $6434.17 \mathrm{~kW}$ ) as well as with the highest energy efficiency (in a range between $53.70 \%$ and $79.40 \%$ ) in comparison to other applicable energy analysis methods. For the observed loads, whole main turbine exergy destruction is in range from $608.64 \mathrm{~kW}$ to $5922.86 \mathrm{~kW}$, while the exergy efficiency range of the whole turbine is between $54.94 \%$ and $80.73 \%$. Exergy analysis and all three applicable energy analysis methods show that increase in the main turbine load results with simultaneous increase in turbine losses and efficiencies (both energy and exergy).
\end{abstract}

Keywords: main marine steam turbine, exergy analysis, various energy analysis methods, different steam turbine loads 


\section{Introduction}

Diesel engines are today the dominant power producers used in marine propulsion systems. The most common arrangement is that for the propulsion are used slow speed two-stroke diesel engines [1-6], while medium or fast speed four-stroke diesel engines are used as an auxiliary engines (mostly for the electrical generator drive) [7-10]. Due to its dominant presence in marine propulsion systems, various researchers are developing numerical models which simulate operating parameters of diesel engines [11-14] and improve their operation $[15,16]$. Reducing of harmful environmental emissions from diesel engine combustion gasses is nowadays one of the most important research topics, therefore various authors presented systems and techniques which reduces (at least partially) harmful emissions from the diesel engines [17-19]. Due to increasing usage of diesel engines in a worldwide fleet, it can be expected that regulation will become each year more rigorous along with further development of processes and systems related to diesel engines [20,21].

Along with diesel engines, nowadays are also under development various propulsion alternatives which are at least partially based on the gas or steam turbines $[22,23]$. Such propulsion systems are very complex because they are assembled of various different components [24,25]. These complex systems require proper economic analysis [26] as well as operational risk assessment [27] before its final implementation. There are various numerical methods which allow optimal propulsion system selection (from the several aspects) for each ship type [28, 29].

The share of steam propulsion systems is the entire worldwide fleet is low, but such systems are still dominant in the propulsion of LNG (Liquefied Natural Gas) carriers due to the specificity of its operation and the transported cargo [30-32]. New LNG carriers are mostly built with propulsion systems which are not related to steam, therefore, it can be expected that steam propulsion systems will, in a recent future, lost its dominance also in these ship types [33-35].

This paper presents an analysis of main marine steam turbine, used for the propulsion of the commercial LNG carrier. Main turbine is analyzed at four different loads by using exergy and four energy analysis methods. Energy and exergy analyses are commonly used methods for investigating various power systems, its components and elements [36-38] with an aim to evaluate the efficiencies and losses during operation, as well as to detect improvement possibility $[39,40]$. For the main marine steam turbine is detected which energy analysis method gives unreliable results without the knowledge of additional losses. Other three energy analysis methods are compared to exergy analysis for proper evaluation of the obtained results. Also, for each applicable method are detected characteristics of expected results (in terms of turbine efficiencies and losses). The obtained conclusions from the analysis performed in this paper are applicable not only to the observed, but also to any other steam turbine. 


\section{Description and operating characteristics of the analyzed main marine steam turbine}

Main marine steam turbine analyzed in this paper is used for the commercial LNG carrier drive [31]. The overall scheme of the entire marine steam propulsion plant without steam re-heating, inside which operates such main turbine can be found in [41].

The general scheme of the observed main marine steam turbine, along with operating points required for the analysis performed in this paper, is presented in Figure 1. From Figure 1 can be seen that main turbine is used not only for the ship propulsion, but also for heat delivery to marine regenerative condensate/feed water heating system and auxiliary systems $[42,43]$.

The analyzed main marine steam turbine is composed of two cylinders - High Pressure Cylinder (HPC) and Low Pressure Cylinder (LPC). Steam produced in marine steam generators [44] is delivered firstly to the HPC through which it expanded. HPC has one steam extraction which lead a certain amount of steam to ship auxiliary systems [45]. After the HPC, steam enters into the LPC before which is mounted second steam extraction (extraction between cylinders) which leads a certain amount of steam to high pressure feed water heating system, Figure 1. LPC also has one steam extraction which leads steam to low pressure condensate heating system [46]. After expansion in the LPC, steam has low temperature and pressure quite above the atmospheric pressure, so it is delivered to the main marine steam condenser [47-49]. It should be highlighted that the cooling water (sea water) delivery to the main marine steam condenser significantly differ in comparison to steam condensers from the land-based thermal power plants [50, 51]. As presented in Figure 1, each steam extraction has valves [52, 53] for regulating the steam mass flow rate (and in some cases pressure) to each steam consumer. Extracted steam mass flow rate in each of three main turbine extractions is dependable on the current load of the whole steam propulsion plant $[54,55]$.

Both main steam turbine cylinders (HPC and LPC) are connected to the main gearbox [56], throughout which is driven main propulsion shaft and propulsion propeller [57].

Main marine steam turbine analyzed in this paper, Figure 1, is an older main steam turbine version in such propulsion systems. Newer versions possess steam reheating between high pressure and middle pressure cylinders, therefore newer main turbine variants are composed of three cylinders [32] what bring many benefits but also increases the whole plant complexity.

Inside marine steam propulsion plants, main propulsion steam turbine is not the only steam turbine - such plants possess steam turbines for the electrical generator drive (turbo-generators) [58] and low power steam turbine for the main feed water pump drive $[59,60]$. However, the main steam turbine is much more complex than all the other mentioned ones (regardless is it older or newer version) and from many aspects more interesting for the analysis. 


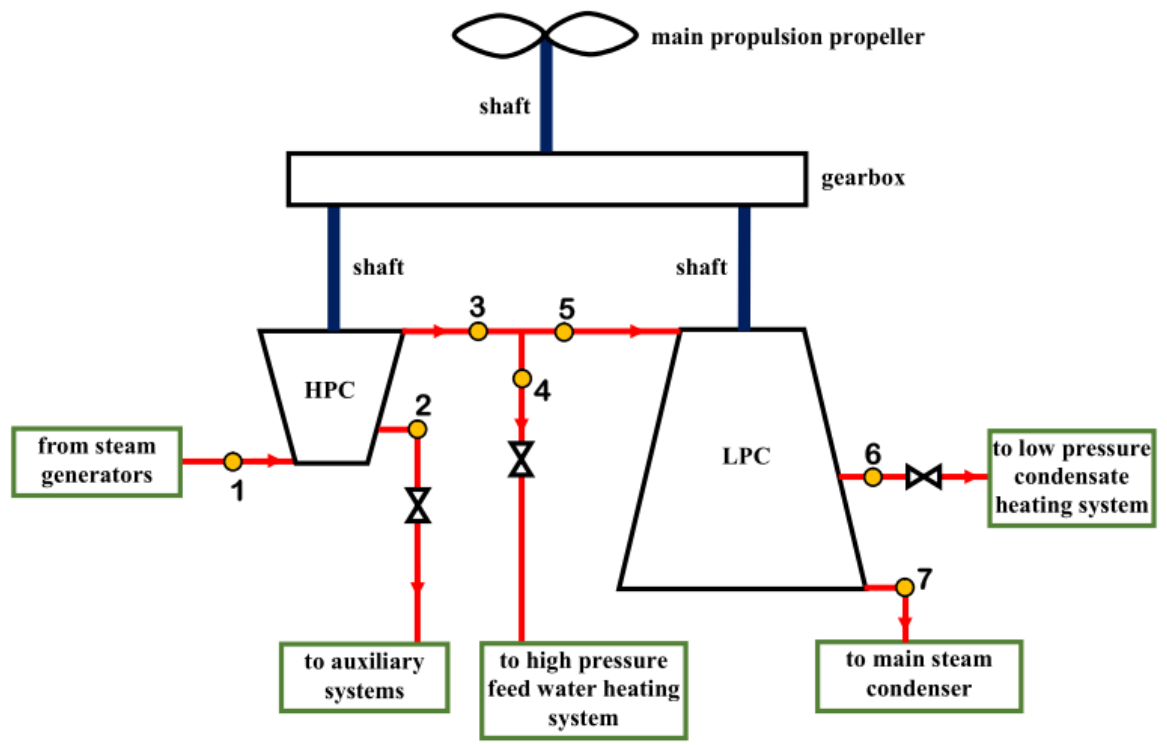

Figure 1 - Scheme of the observed main marine steam turbine from the LNG carrier along with marked operating points required for the analysis

\section{Energy and exergy analysis}

\subsection{General energy and exergy equations and balances}

In the energy and exergy analyses of any complex system, control volume or a set of control volumes, there exist several general equations and balances which are essential [61]. All of those equations and balances will be also used during the analysis of main marine steam turbine, regardless of used method or sub-method.

The first law of thermodynamics is a baseline for the energy analysis, what is proven in many researches so far [62-64]. General energy balance equation, valid in energy analysis of any system or a control volume is $[65,66]$ :

$$
\dot{Q}_{\text {inlet }}+P_{\text {inlet }}+\sum \dot{E} n_{\text {inlet }}=\dot{Q}_{\text {outlet }}+P_{\text {outlet }}+\sum \dot{E} n_{\text {outlet }} .
$$

In the general energy balance equation (Eq. 1) potential and kinetic energies are disregarded due to its low influence on the overall balance [67]. In Eq. 1 and throughout this paper, $P$ in $(\mathrm{kW})$ is used or produced mechanical power, $\dot{Q}$ in $(\mathrm{kW})$ is energy heat transfer, while $\dot{E}$ in $(\mathrm{kW})$ is a total flow energy (of any fluid stream), which can be defined according to [68] as: 


$$
\dot{E} n=\dot{m} \bullet h \text {. }
$$

In Eq. 2 and throughout this paper, $\dot{m}$ in $(\mathrm{kg} / \mathrm{s}$ or $\mathrm{kg} / \mathrm{h})$ is the fluid mass flow rate, while $h$ in $(\mathrm{kJ} / \mathrm{kg})$ is fluid specific enthalpy.

The second law of thermodynamics, which is related to the change in fluid specific entropy, is a baseline for the exergy analysis of any system or a control volume [69, 70]. General exergy balance equation, according to [71, 72], is:

$$
\dot{X}_{\text {heat }}+P_{\text {inlet }}+\sum \dot{E} x_{\text {inlet }}=P_{\text {outlet }}+\sum \dot{E} x_{\text {outlet }}+\dot{E} x_{\text {Destruction }} .
$$

In Eq. 3 and throughout this paper, $\dot{E} x_{\text {Destruction }}$ is exergy destruction (exergy loss) in $(\mathrm{kW})$, while $\dot{X}_{\text {heat }}$ in $(\mathrm{kW})$ is an exergy heat transfer at the temperature $T$, which can be defined by the equation $[73,74]$ :

$$
\dot{X}_{\text {heat }}=\sum\left(1-\frac{T_{0}}{T}\right) \cdot \dot{Q} .
$$

In Eq. 4, $T$ is a temperature in (K). Throughout this paper, temperatures can also be found in $\left({ }^{\circ} \mathrm{C}\right)$. Index 0 is related to the ambient state, not only in Eq. 4, but also throughout this paper. $\dot{E} x$ in $(\mathrm{kW})$ is a total flow exergy (of any fluid stream), which is calculated according to $[75,76]$ by using an equation:

$$
\dot{E} x=\dot{m} \bullet \varepsilon .
$$

Definition of a total flow energy (Eq. 2) and total flow exergy (Eq. 5) will also be directly used in the energy and exergy analyses of the main marine steam turbine. In Eq. 5 and throughout the paper text, is specific exergy of any fluid stream in $(\mathrm{kJ} / \mathrm{kg})$, which is defined, according to $[77,78]$, by an equation:

$$
\varepsilon=\left(h-h_{0}\right)-T_{0} \bullet\left(s-s_{0}\right) .
$$

In Eq. 6, the ambient temperature () must be in (K), while not only in Eq. 6 but also throughout the paper text, in $(\mathrm{kJ} / \mathrm{kg} \cdot \mathrm{K})$ is fluid stream specific entropy.

General energy or exergy efficiency definition of any system or a control volume can be found in [79-81] and calculated by using an equation:

$$
\eta_{\text {en(ex) }}=\frac{\text { cumulative energy }(\text { exergy) output }}{\text { cumulative energy }(\text { exergy }) \text { input }} .
$$

During a standard operation of any complex system, control volume or a set of control volumes, mass flow rate leakage (of any fluid stream) did not occur $[82,83]$. Therefore, for a standard operation is valid mass flow rate balance [84]: 


$$
\sum \dot{m}_{\text {inlet }}=\sum \dot{m}_{\text {outlet }}
$$

\subsection{Energy and exergy analyses of the main marine steam turbine}

In the energy and exergy analyses of main marine steam turbine, essential component is a definition of real (polytropic) power developed by both turbine cylinders, Figure 1. Real (polytropic) power of both main marine steam turbine cylinders (as well as of any other steam turbine cylinder [85]) can be calculated according to real expansion process presented in Figure 2. In should be noted that operating points of the real expansion process in Figure 2 are defined in accordance with operating points presented in Figure 1 and will be used in the equations for real (polytropic) power of the whole main marine steam turbine and both of its cylinders.

Real (polytropic) power of HPC at each load is calculated by using an equation:

$$
P_{\mathrm{re}, \mathrm{HPC}}=\dot{m}_{1} \bullet\left(h_{1}-h_{2}\right)+\left(\dot{m}_{1}-\dot{m}_{2}\right) \cdot\left(h_{2}-h_{3}\right) \text {. }
$$

Real (polytropic) power of LPC at each load is calculated by using an equation:

$$
P_{\mathrm{re}, \mathrm{LPC}}=\left(\dot{m}_{1}-\dot{m}_{2}-\dot{m}_{4}\right) \cdot\left(h_{3}-h_{6}\right)+\left(\dot{m}_{1}-\dot{m}_{2}-\dot{m}_{4}-\dot{m}_{6}\right) \cdot\left(h_{6}-h_{7}\right) \text {. }
$$

Real (polytropic) power of the whole main marine steam turbine (WT) at each load is calculated by using an equation:

$$
P_{\mathrm{re}, \mathrm{WT}}=P_{\mathrm{re}, \mathrm{HPC}}+P_{\mathrm{re}, \mathrm{LPC}} .
$$

Main marine steam turbine measurement results (presented later in the paper text in Table 1 and Table 2) show that steam in operating points 3, 4 and 5 (Figure 1 and Figure 2) have the same temperature and pressure, while the steam mass flow rate differs in mentioned operating points. The same steam temperature and pressure results with the same steam specific enthalpy and specific entropy in operating points 3,4 and 5, what can clearly be seen in Figure 2. 


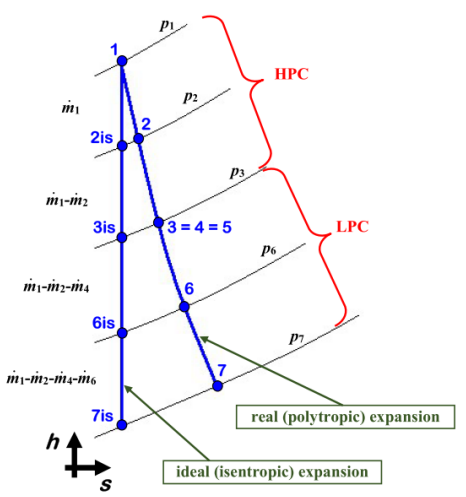

(a)

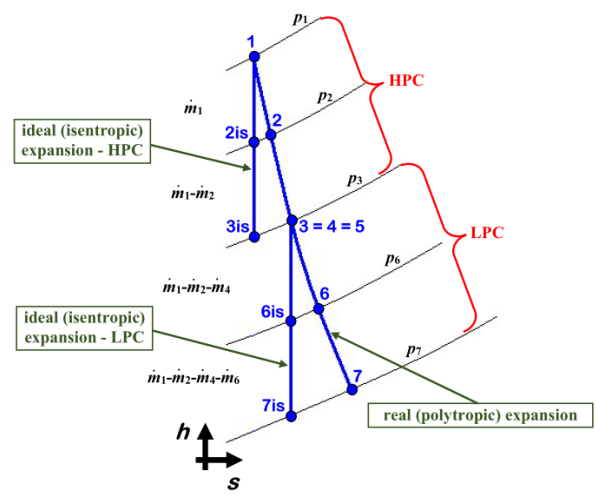

(b)

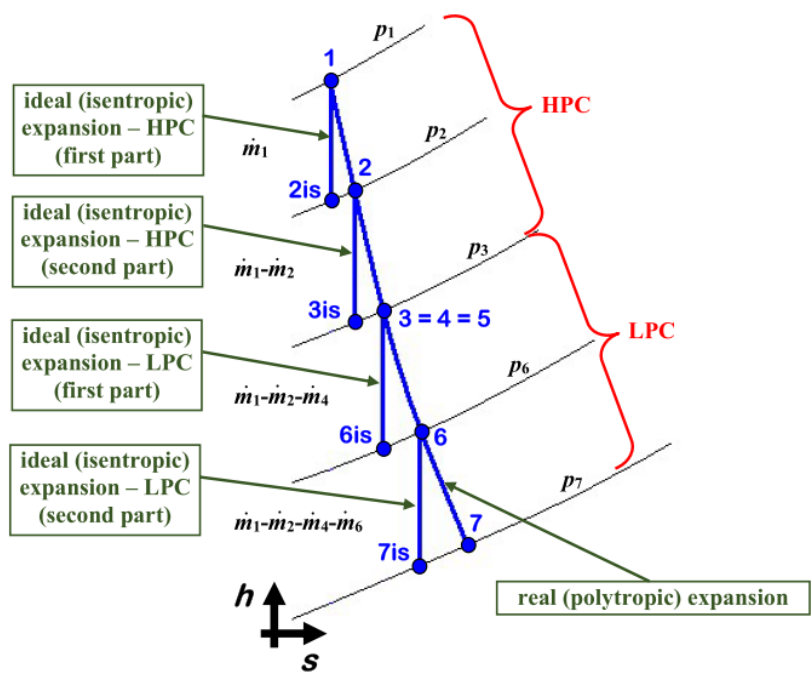

(c)

Figure 2 - Steam expansion processes for a various main turbine energy analysis methods: (a) Second method; (b) Third method; (c) Fourth method

Equations for the main marine steam turbine exergy analysis, as well as equations for all main marine steam turbine energy analyses are defined by using operating points presented in Figure 1 and Figure 2. 


\subsubsection{Main marine steam turbine exergy analysis}

Exergy analysis of the whole main marine steam turbine is based on the total flow exergy (Eq. 5) for each steam stream which enters and exits the observed turbine. Final exergy analysis equations, which defines whole turbine exergy destruction and exergy efficiency are the same at each observed load [86, 87].

Exergy destruction of the whole main marine steam turbine, according to [88], can be defined by using an equation:

$$
\dot{E} x_{\text {Destruction, } \mathrm{WT}}=\dot{E} x_{1}-\dot{E} x_{2}-\dot{E} x_{4}-\dot{E} x_{6}-\dot{E} x_{7}-P_{\mathrm{re}, \mathrm{WT}} .
$$

while exergy efficiency of the whole analyzed main marine steam turbine is defined according to recommendations from [89] as:

$$
\eta_{\mathrm{ex}, \mathrm{WT}}=\frac{P_{\mathrm{re}, \mathrm{WT}}}{\dot{E} x_{1}-\dot{E} x_{2}-\dot{E} x_{4}-\dot{E} x_{6}-\dot{E} x_{7}} .
$$

For the exergy analysis of any system, control volume or a set of control volumes must be defined the base ambient state (dead state) for which calculations will be performed. Exergy analysis of the main marine steam turbine at each observed load is performed for the base ambient state as recommended in [90, 91]:

- Ambient pressure: $p_{0}=1 \mathrm{bar}=0.1 \mathrm{MPa}$,

- Ambient temperature: $T_{0}=25^{\circ} \mathrm{C}=298.15 \mathrm{~K}$.

\subsubsection{Main marine steam turbine energy analysis}

Energy analysis of a steam turbine, regardless of turbine complexity and developed power, can be performed by using several different approaches [92]. For the observed main marine steam turbine can be used four different energy analysis approaches. All of them can be used not for the analyzed main marine steam turbine only, but also for the energy analysis of any other steam turbine.

\subsubsection{Method 1 (M1)}

The first energy analysis method applied to the main marine steam turbine is a method which uses the total flow energy (Eq. 2) for each steam stream which enters and exits the observed turbine. Final equations for calculating the whole turbine energy loss (energy destruction) and energy efficiency by using this method are the same as in exergy analysis, the only difference is replacing total flow exergy of each fluid stream with total flow energy. In this energy analysis method various losses which occur inside the turbine (mechanical losses, steam mass flow rates lost through front and rear gland seals, losses during steam expansion, etc.) are disregarded. 
Energy loss of the whole main marine steam turbine by using this method can be defined with an equation:

$$
\dot{E} n_{\text {Loss, } \mathrm{WT}, \mathrm{M} 1}=\dot{E} n_{1}-\dot{E} n_{2}-\dot{E} n_{4}-\dot{E} n_{6}-\dot{E} n_{7}-P_{\mathrm{re}, \mathrm{WT}} .
$$

while energy efficiency of the whole main marine steam turbine in this energy analysis method is defined by an equation:

$$
\eta_{\mathrm{en}, \mathrm{WT}, \mathrm{Ml}}=\frac{P_{\mathrm{re}, \mathrm{WT}}}{\dot{E} n_{1}-\dot{E} n_{2}-\dot{E} n_{4}-\dot{E} n_{6}-\dot{E} n_{7}} .
$$

From Eq. 14 and Eq. 15 can clearly be seen that the first observed energy analysis method takes into consideration real (polytropic) power. Also, neither in Eq. 14 or in Eq. 15 are not taken into consideration losses during steam expansion (comparison of real and ideal steam expansion processes).

\subsubsection{Method 2 (M2)}

Main marine steam turbine energy analysis methods 2, 3 and 4 are based on the comparison of steam expansion processes presented in Figure 2. In all these methods, real (polytropic) steam expansion process inside the main marine steam turbine cylinders is always the same, the different are only ideal (isentropic) steam expansion processes due to different positions of its application. Ideal (isentropic) steam expansion process, regardless of its position, assumes always the same steam specific entropy during expansion. In the real (polytropic) steam expansion process throughout any turbine steam specific entropy continuously increases, so ideal (isentropic) steam expansion process is the best expansion possibility, because the ideal process neglected all the losses (increase in steam specific entropy) which occurs during such process.

Method 2 for the main marine steam turbine energy analysis is based on the comparison of ideal and real steam expansion processes presented in Figure 2 (a). In this method, ideal (isentropic) steam expansion process is only one - it begins at the main marine steam turbine inlet (operating point 1 ) and lasts until the outlet pressure $\left(p_{7}\right)$ of the whole turbine (main condenser pressure). As the steam specific entropy remains always the same during the ideal expansion process, the last operating point of the ideal process by using this method is operating point 7 is, Figure 2 (a).

In this energy analysis method, real (polytropic) power of the whole turbine is calculated by using Eq. 11, while ideal (isentropic) power of the whole turbine can be calculated according to the expansion process from Figure 2 (a) by using the equation:

$$
\begin{aligned}
P_{\mathrm{id}, \mathrm{WT}, \mathrm{M} 2} & =\dot{m}_{1} \cdot\left(h_{1}-h_{2 \mathrm{is}}\right)+\left(\dot{m}_{1}-\dot{m}_{2}\right) \cdot\left(h_{2 \mathrm{is}}-h_{\mathrm{3is}}\right)+\left(\dot{m}_{1}-\dot{m}_{2}-\dot{m}_{4}\right) \cdot \\
& \cdot\left(h_{\mathrm{3is}}-h_{6 \mathrm{is}}\right)+\left(\dot{m}_{1}-\dot{m}_{2}-\dot{m}_{4}-\dot{m}_{6}\right) \cdot\left(h_{6 \mathrm{is}}-h_{\mathrm{7is}}\right) .
\end{aligned}
$$


Energy loss of the whole main marine steam turbine by using this method can be calculated according to the following equation:

$$
\dot{E} n_{\mathrm{Loss}, \mathrm{WT}, \mathrm{M} 2}=P_{\mathrm{id}, \mathrm{WT}, \mathrm{M} 2}-P_{\mathrm{re}, \mathrm{WT}} \text {. }
$$

while energy efficiency of the whole main marine steam turbine by using this energy analysis method is defined with an equation:

$$
\eta_{\mathrm{en}, \mathrm{WT}, \mathrm{M} 2}=\frac{P_{\mathrm{re}, \mathrm{WT}}}{P_{\mathrm{id}, \mathrm{WT}, \mathrm{M} 2}} .
$$

Regardless of the calculation procedure, the ideal (isentropic) power of the whole turbine will always be higher than real (polytropic) power, because the ideal power did not contain any steam expansion losses.

\subsubsection{Method 3 (M3)}

Method 3 for the main marine steam turbine energy analysis is based on the comparison of ideal and real steam expansion processes presented in Figure 2 (b). In this method, ideal (isentropic) steam expansion process is divided in two parts - the first part is related to ideal expansion inside HPC, while the second part is related to ideal expansion inside LPC. Each ideal (isentropic) expansion process begins at the inlet of each turbine cylinder (HPC and LPC).

As in Method 2, real (polytropic) power of the whole turbine is calculated by using Eq. 11, while ideal (isentropic) power of the whole turbine can be calculated according to the expansion process from Figure 2 (b) by using the equation:

$$
\begin{aligned}
P_{\mathrm{id}, \mathrm{WT}, \mathrm{M} 3}= & \dot{m}_{1} \cdot\left(h_{1}-h_{2 \mathrm{is}}\right)+\left(\dot{m}_{1}-\dot{m}_{2}\right) \cdot\left(h_{\mathrm{is}}-h_{\mathrm{iss}}\right)+\left(\dot{m}_{1}-\dot{m}_{2}-\dot{m}_{4}\right) \cdot \\
& \cdot\left(h_{3}-h_{\text {6is }}\right)+\left(\dot{m}_{1}-\dot{m}_{2}-\dot{m}_{4}-\dot{m}_{6}\right) \cdot\left(h_{\text {6is }}-h_{\text {7is }}\right) .
\end{aligned}
$$

Energy loss of the whole main marine steam turbine by using Method 3 can be calculated according to the following equation:

$$
\dot{E} n_{\mathrm{Loss}, \mathrm{WT}, \mathrm{M} 3}=P_{\mathrm{id}, \mathrm{WT}, \mathrm{M} 3}-P_{\mathrm{re}, \mathrm{WT}} \text {. }
$$

while energy efficiency of the whole main marine steam turbine by using Method 3 is defined with an equation:

$$
\eta_{\mathrm{en}, \mathrm{WT}, \mathrm{M} 3}=\frac{P_{\mathrm{re}, \mathrm{WT}}}{P_{\mathrm{id}, \mathrm{WT}, \mathrm{M} 3}} .
$$




\subsubsection{Method 4 (M4)}

Fourth and the last main marine steam turbine energy analysis method is based on the comparison of ideal and real steam expansion processes presented in Figure 2 (c). In this method, ideal (isentropic) steam expansion process is divided into four parts - each ideal steam expansion process begins at the inlet of each turbine cylinder and at the steam extraction from each turbine cylinder. As HPC and LPC have one steam extraction each, the entire ideal (isentropic) steam extraction process is divided on the four different parts.

As in Methods 2 and 3, real (polytropic) power of the whole turbine is calculated by using Eq. 11, while ideal (isentropic) power of the whole turbine in Method 4 can be calculated according to the expansion process from Figure 2 (c) by using the equation:

$$
\begin{aligned}
P_{\mathrm{id}, \mathrm{WT}, \mathrm{M} 4} & =\dot{m}_{1} \cdot\left(h_{1}-h_{2 \mathrm{is}}\right)+\left(\dot{m}_{1}-\dot{m}_{2}\right) \cdot\left(h_{2}-h_{3 \mathrm{is}}\right)+\left(\dot{m}_{1}-\dot{m}_{2}-\dot{m}_{4}\right) \cdot \\
& \cdot\left(h_{3}-h_{6 \mathrm{is}}\right)+\left(\dot{m}_{1}-\dot{m}_{2}-\dot{m}_{4}-\dot{m}_{6}\right) \cdot\left(h_{6}-h_{\mathrm{is}}\right) .
\end{aligned}
$$

Energy loss of the whole main marine steam turbine by using Method 4 can be calculated according to the following equation:

$$
\dot{E} n_{\mathrm{Loss}, \mathrm{WT}, \mathrm{M} 4}=P_{\mathrm{id}, \mathrm{WT}, \mathrm{M} 4}-P_{\mathrm{re}, \mathrm{WT}} .
$$

while energy efficiency of the whole main marine steam turbine by using Method 4 is defined with an equation:

$$
\eta_{\mathrm{en}, \mathrm{WT}, \mathrm{M} 4}=\frac{P_{\mathrm{re}, \mathrm{WT}}}{P_{\mathrm{id}, \mathrm{WT}, \mathrm{M} 4}} .
$$

\section{Main marine steam turbine measurement results and measuring equipment}

Measurement results of the main marine steam turbine in each operating point from Figure 1 at four different loads are presented in Table 1 and Table 2. Table 1 presents the measurement results in operating points related to HPC and in extraction between HPC and LPC, while Table 2 presents the measurement results in operating points related to LPC.

Main marine steam turbine load in Table 1 and Table 2 is represented by propulsion propeller speed. Propulsion propeller speed is directly proportional to main marine steam turbine load - higher propulsion propeller speed denotes higher main steam turbine load and vice versa.

In Table 3 is presented steam content at the LPC outlet (main steam condenser inlet) in all four observed propulsion propeller speeds (main turbine loads). From Table 
3 should be highlighted two important elements. The first element is that increase in main marine steam turbine load resulted with lower steam content at the LPC outlet. The second important element is the lowest observed main marine steam turbine load - from Table 3 can be seen that steam at the main condenser inlet at low load $(25.58 \mathrm{rpm})$ is still superheated. Superheated steam cannot be easily transferred to condensate, therefore at such low main turbine loads in the main steam condenser is injected additional amount of water for steam cooling purposes. Steam cooling resulted by transferring steam under the saturation line where two phases (steam and water droplets) occur. After obtaining two phases, saturated steam is turning into a condensate by heat transfer to cooling water (heat transfer occurs at the walls of each condenser tube through which passes cooling water - two convections and conduction).

Measurement results were obtained during the LNG carrier travel from the port to the open sea. The highest observed main marine steam turbine load $(83.00 \mathrm{rpm})$ is approximately equal to $85 \%$ of the main turbine maximum power, where the specific fuel consumption in marine steam generators is the lowest. All obtained analyses results presented in this paper will be shown in relation to propulsion propeller speeds from Table 1, Table 2 and Table 3.

Table 1 - Main marine steam turbine measurement results - HPC and extraction between cylinders

\begin{tabular}{|c|c|c|c|c|c|c|c|c|c|c|c|c|}
\hline \multirow{2}{*}{$\begin{array}{l}\text { Propulsion } \\
\text { propeller } \\
\text { speed (rpm) }\end{array}$} & \multicolumn{3}{|c|}{$\begin{array}{l}\text { High pressure } \\
\text { cylinder inlet } \\
\text { (O.P. 1) }\end{array}$} & \multicolumn{3}{|c|}{$\begin{array}{c}\text { High pressure } \\
\text { cylinder extraction } \\
(\text { O.P. 2) }\end{array}$} & \multicolumn{3}{|c|}{$\begin{array}{l}\text { High pressure } \\
\text { cylinder outlet } \\
\text { (O.P. 3) }\end{array}$} & \multicolumn{3}{|c|}{$\begin{array}{c}\text { Extraction between } \\
\text { cylinders } \\
\text { (O.P. 4) }\end{array}$} \\
\hline & $\begin{array}{c}T \\
\left({ }^{\circ} \mathrm{C}\right)\end{array}$ & $\begin{array}{c}p \\
\text { (MPa) }\end{array}$ & $\begin{array}{c}\dot{m} \\
(\mathrm{~kg} / \mathrm{h})\end{array}$ & $\begin{array}{c}T \\
\left({ }^{\circ} \mathrm{C}\right)\end{array}$ & $\begin{array}{c}p \\
\text { (MPa) }\end{array}$ & $\begin{array}{c}\dot{m} \\
(\mathrm{~kg} / \mathrm{h})\end{array}$ & $\begin{array}{c}T \\
\left({ }^{\circ} \mathrm{C}\right)\end{array}$ & $\begin{array}{c}p \\
\text { (MPa) }\end{array}$ & $\begin{array}{c}\dot{m} \\
(\mathrm{~kg} / \mathrm{h})\end{array}$ & $\begin{array}{c}T \\
\left({ }^{\circ} \mathrm{C}\right)\end{array}$ & $\begin{array}{c}p \\
\text { (MPa) }\end{array}$ & $\begin{array}{c}\dot{m} \\
(\mathrm{~kg} / \mathrm{h})\end{array}$ \\
\hline 25. & 485 & 6.2 & 3835 & - & - & - & 231.0 & 0.048 & 383 & . & - & - \\
\hline 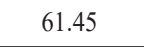 & 496 & 5.969 & 37642 & - & - & - & 0 & 0.295 & 3764 & - & - & - \\
\hline 71.03 & 511 & 6.078 & 53177 & - & 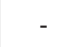 & - & 0 & 0.413 & 53 & - & - & - \\
\hline 83.00 & 500 & 5.899 & 96183 & 350 & 1.565 & 3268 & 256.4 & 0.593 & 92915 & 256.4 & 0.593 & 13167 \\
\hline
\end{tabular}

* $\quad T=$ temperature; $p=$ pressure; $\dot{m}=$ mass flow rate

** O.P. $=$ Operating Point (in relation to Figure 1 and Figure 2) 
Table 2 - Main marine steam turbine measurement results - LPC

\begin{tabular}{|c|c|c|c|c|c|c|c|c|c|}
\hline \multirow{2}{*}{$\begin{array}{c}\text { Propulsion } \\
\text { propeller } \\
\text { speed } \\
\text { (rpm) } \\
\end{array}$} & \multicolumn{3}{|c|}{$\begin{array}{l}\text { Low pressure cylinder inlet } \\
\text { (O.P. 5) }\end{array}$} & \multicolumn{3}{|c|}{$\begin{array}{l}\text { Low pressure cylinder } \\
\text { extraction (O.P. 6) }\end{array}$} & \multicolumn{3}{|c|}{$\begin{array}{l}\text { Low pressure cylinder outlet } \\
\text { (O.P. 7) }\end{array}$} \\
\hline & $T\left({ }^{\circ} \mathrm{C}\right)$ & $\begin{array}{c}p \\
(\mathrm{MPa}) \\
\end{array}$ & $\begin{array}{c}\dot{m} \\
(\mathrm{~kg} / \mathrm{h})\end{array}$ & $T\left({ }^{\circ} \mathrm{C}\right)$ & $\begin{array}{c}p \\
(\mathrm{MPa})\end{array}$ & $\begin{array}{c}\dot{m} \\
(\mathrm{~kg} / \mathrm{h})\end{array}$ & $\begin{array}{c}T \\
\left({ }^{\circ} \mathrm{C}\right) \\
\end{array}$ & $\begin{array}{c}p \\
(\mathrm{MPa}) \\
\end{array}$ & $\dot{m}(\mathrm{~kg} / \mathrm{h})$ \\
\hline 25.58 & 231.0 & 0.048 & 3835 & - & - & - & 100.02 & 0.005408 & 3835 \\
\hline 61.45 & 279.0 & 0.295 & 37642 & - & - & - & 30.12 & 0.004276 & 37642 \\
\hline 71.03 & 265.0 & 0.413 & 53177 & 163 & 0.088 & 1876 & 28.90 & 0.003987 & 51301 \\
\hline 83.00 & 256.4 & 0.593 & 79748 & 153 & 0.121 & 3256 & 34.92 & 0.005605 & 76492 \\
\hline
\end{tabular}

* $\quad T=$ temperature; $p=$ pressure $; \dot{m}=$ mass flow rate

** $\quad$ O.P. $=$ Operating Point (in relation to Figure 1 and Figure 2)

Table 3 - Steam content at the LPC outlet (main steam condenser inlet)

\begin{tabular}{|c|c|}
\hline $\begin{array}{c}\text { Propulsion } \\
\text { propeller speed } \\
\text { (rpm) }\end{array}$ & $\begin{array}{c}\text { Steam content at the LPC } \\
\text { outlet (\%) }\end{array}$ \\
25.58 & Superheated \\
\hline 61.45 & 94.16 \\
\hline 71.03 & 93.54 \\
\hline 83.00 & 92.13 \\
\hline
\end{tabular}

Measurement results were obtained by using measuring equipment which was already mounted in all operating points presented in Figure 1. The measuring equipment is normally used during main marine steam turbine exploitation for a control and regulation purposes. The list of measuring equipment, for each operating point in Figure 1, is presented in Table 4. 
Table 4-List of used measurement equipment

\begin{tabular}{|c|c|c|c|}
\hline $\begin{array}{c}\text { Operating } \\
\text { Point* }\end{array}$ & Steam mass flow rate [93] & Steam pressure [94] & Steam temperature [95] \\
\hline $\mathbf{1}$ & Yamatake JTD960A & Yamatake JTG960A & Greisinger GTF 601-Pt100 \\
\hline $\mathbf{2}$ & Yamatake JTD960A & Yamatake JTG940A & Greisinger GTF 601-Pt100 \\
\hline $\mathbf{3}$ & Yamatake JTD930A & Yamatake JTG940A & Greisinger GTF 401-Pt100 \\
\hline $\mathbf{4}$ & Yamatake JTD930A & Yamatake JTG940A & Greisinger GTF 401-Pt100 \\
\hline $\mathbf{5}$ & Yamatake JTD930A & Yamatake JTG940A & Greisinger GTF 401-Pt100 \\
\hline $\mathbf{6}$ & Yamatake JTD920A & Yamatake JTG940A & Greisinger GTF 401-Pt100 \\
\hline $\mathbf{7}$ & Yamatake JTD910A & Yamatake JTG940A & Greisinger GTF 401-Pt100 \\
\hline $\begin{array}{c}\text { Propulsion } \\
\text { propeller } \\
\text { speed [96] }\end{array}$ & $\begin{array}{c}\text { Kyma Shaft Power Meter } \\
\text { (KPM-PFS) }\end{array}$ & & \\
\hline
\end{tabular}

* According to Figure 1

Steam specific enthalpies and specific entropies required in the equations for the main marine steam turbine energy and exergy analyses are calculated from known pressure and temperature (Table 1 and Table 2) in each operating point of the analyzed turbine (Figure 1) by using NIST-REFPROP 9.0 software [97]. Steam specific exergies, also in each operating point of the analyzed main marine steam turbine, are calculated by using Eq. 6 for the base ambient state defined in Section 3.2.1.

\section{Results and discussion}

Real (polytropic) power of the whole analyzed main steam turbine and its distribution to HPC and LPC at each observed load is presented in Figure 3.

From Figure 3 can clearly be seen increase in main marine steam turbine real (polytropic) power during the increase in propulsion propeller speed (from $742.22 \mathrm{~kW}$ at $25.58 \mathrm{rpm}$ up to $24805.38 \mathrm{~kW}$ at $83.00 \mathrm{rpm}$ ), what confirms previously explained fact that the main propulsion steam turbine load and propulsion propeller speed are directly proportional.

The distribution of the whole turbine real developed power on the turbine cylinders shows one interesting and important fact. At the lowest observed main turbine load (25.58 rpm), HPC produces higher part of real power in comparison to LPC. Increase in main turbine load resulted with a fact that the higher part of a real power produces LPC (in comparison to HPC). Therefore, it can be concluded that at low main marine steam turbine loads, the dominant power producer is HPC, while at all the other main turbine loads (middle and high loads), the dominant power producer is LPC, what is in accordance with the conclusions presented in [31]. 


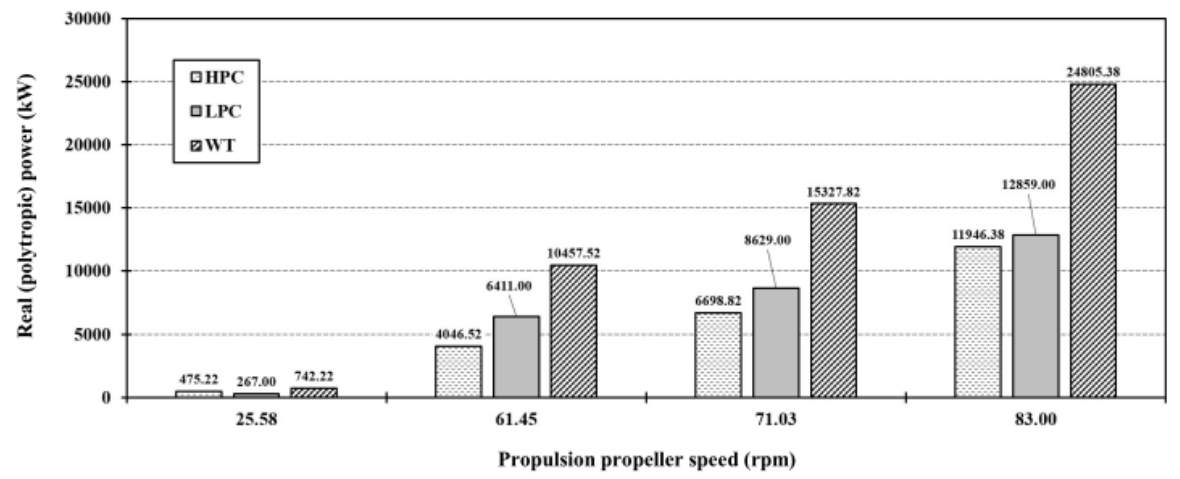

Figure 3 - Real (polytropic) power of the whole analyzed main marine steam turbine and both of its cylinders at four different loads

In this paper are observed and explained four different energy analysis methods of the same main marine steam turbine. In Method 1 is used real (polytropic) power of the whole steam turbine, therefore Method 1 did not observed ideal (isentropic) steam expansion process throughout the analyzed main marine steam turbine.

In an energy analysis Methods 2, 3 and 4 are observed different ideal (isentropic) steam expansion processes throughout the main marine turbine. In Method 2 ideal (isentropic) steam expansion process is only one from the HPC inlet up to LPC outlet. In Method 3 ideal steam expansion is divided on two cylinders (HPC and LPC), while in Method 4 ideal steam expansion is divided on the inlet of each cylinder as well as on steam extractions from each cylinder.

From Figure 4 can be observed that division of one ideal (isentropic) steam expansion process - Method 2, to two ideal expansion processes - Method 3, and finally to four ideal expansion processes - Method 4, resulted with higher and higher ideal (isentropic) power of the whole main marine steam turbine. At each observed load, ideal (isentropic) power of the whole main turbine is the highest in Method 4 and the lowest in Method 2. The reasons of such occurrence will be further explained by using Figure 5. 


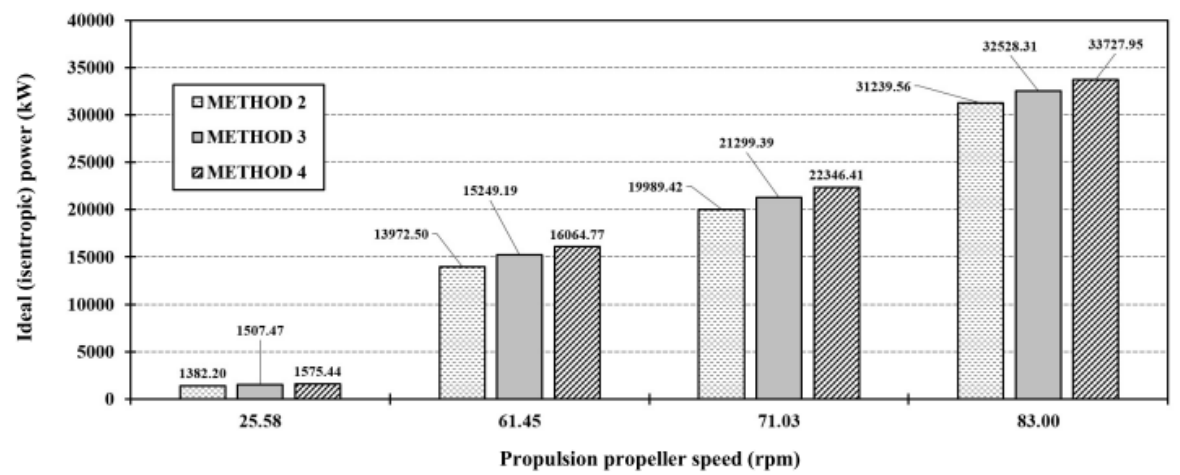

Figure 4 - Ideal (isentropic) power of the whole analyzed main marine steam turbine by using different energy analysis methods (Methods 2, 3 and 4)

Dividing of one ideal (isentropic) steam expansion process (Method 2), to two or more ideal expansion processes (Method 3 and Method 4) for the same steam turbine, leads to higher and higher steam specific entropies, Figure 5. Between two the same constant pressures, ideal steam expansion process will result with a higher specific enthalpy difference (ideal specific work) for a higher specific entropy than for a lower specific entropy, Figure 5.

For the analyzed main marine steam turbine, an increase in the number of ideal expansion process divisions leads to the field of higher specific entropies (to higher ideal specific work between the same pressures). Finally, higher number of ideal expansion process divisions will lead to higher ideal power of the analyzed turbine, Figure 4 and Figure 5. The performed conclusions related to Figure 5 are valid for any steam turbine at any load (not only for the observed main marine steam turbine). 


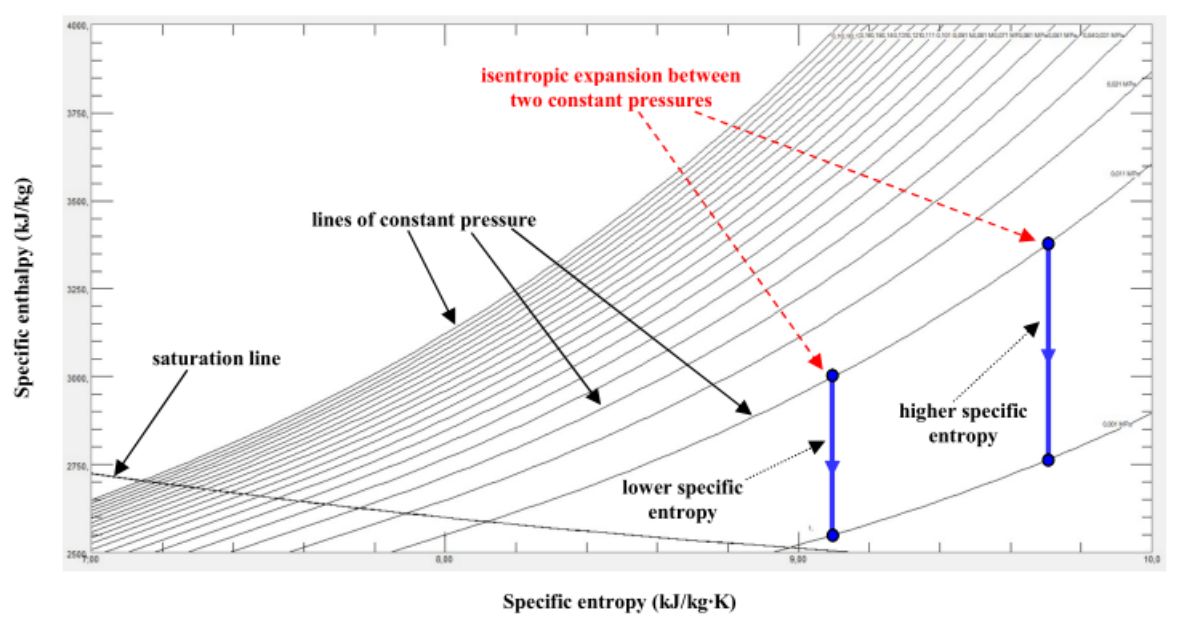

Figure 5 - Ideal (isentropic) steam expansion process between two constant pressures in h-s diagram at lower and higher specific entropy

As stated before, in the energy analysis Method 1 are used total flow energy streams and real (polytropic) turbine power. For the whole main marine steam turbine as well as for each turbine cylinder at any observed load, this method will result with energy loss equal to $0 \mathrm{~kW}$, and consequentially with energy efficiency equal to $100 \%$, Figure 6 and Figure 7. The presented results clearly show that this energy analysis method (which is based on the same principles as an exergy analysis method) cannot be used as a relevant one. The same energy loss and energy efficiency during the use of this method will be obtained for any steam turbine cylinder or for any whole steam turbine at any load (conclusion is based by performing the same calculations for several other steam turbines which operating data were found in the available literature). Energy analysis Method 1 can be used only if the steam turbine losses are known (steam mass flow rates leaked through the gland seals, mechanical losses, additional steam leakages, inner turbine losses, etc.). During steam turbine exploitation it is hard to properly track and measure mentioned losses, therefore the final conclusion related to Method 1 is that it should be avoided in energy analysis of any steam turbine or turbine cylinder.

Other energy analysis methods (Methods 2, 3 and 4), which are based on the comparison of real (polytropic) and ideal (isentropic) steam expansion processes, can be used for the energy analysis of the whole steam turbine. Energy loss of the whole analyzed main marine steam turbine in Methods 2, 3 and 4 is calculated as a difference between the ideal (isentropic) and real (polytropic) power at each turbine load. As an ideal power of the whole turbine increases from Method 2 to Method 4, Figure 4, and the real turbine power is always the same in all energy analysis methods at each load, energy loss of the whole turbine will be the highest for Method 4 and the lowest for 
Method 2, regardless of the observed main marine steam turbine load, Figure 6 . The same conclusion will be obtained by using energy analysis Methods 2, 3 and 4 in the research of any other complex steam turbine.

If observing different main marine steam turbine loads, Figure 6, it can be concluded that the highest energy loss of the whole turbine will be obtained at the highest turbine load (at the highest propulsion propeller speed) and vice versa, regardless of used energy analysis method (Method 1 cannot be included in this comparison).

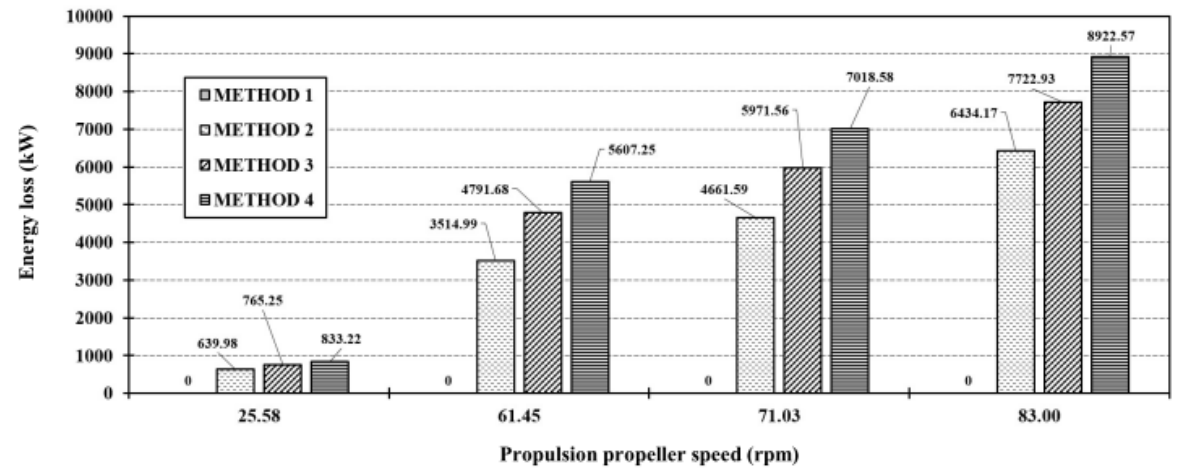

Figure 6 - Energy loss of the whole main marine steam turbine at each observed load by using all energy analysis methods

As concluded from Figure 6, energy efficiency of the main marine (or any other) steam turbine while using Method 1 will be equal to $100 \%$, regardless of turbine load, Figure 7. For all the other energy analysis methods (Methods 2, 3 and 4) can be concluded that energy efficiency and energy loss of the whole turbine are reverse proportional, Figure 7 . The highest main marine steam turbine energy efficiency can be observed in Method 2 (where the energy loss is the lowest), while the lowest energy efficiency can be observed in Method 4 (where the energy loss is the highest), regardless of main marine steam turbine load. Obtained energy efficiency range for the whole main marine steam turbine in Method 2 is between $53.70 \%$ and $79.40 \%$ when taking into account all the observed loads, Figure 7.

While observing various turbine loads, from Figure 7 is obvious that in all the other energy analysis methods except Method 1, energy efficiency of the whole main marine steam turbine increases during the increase in turbine load. Such occurrence that the whole turbine has higher and higher energy efficiency as its load increases is expected, what is another confirmation that the usage of Methods 2, 3 and 4 is acceptable in any conditions. 


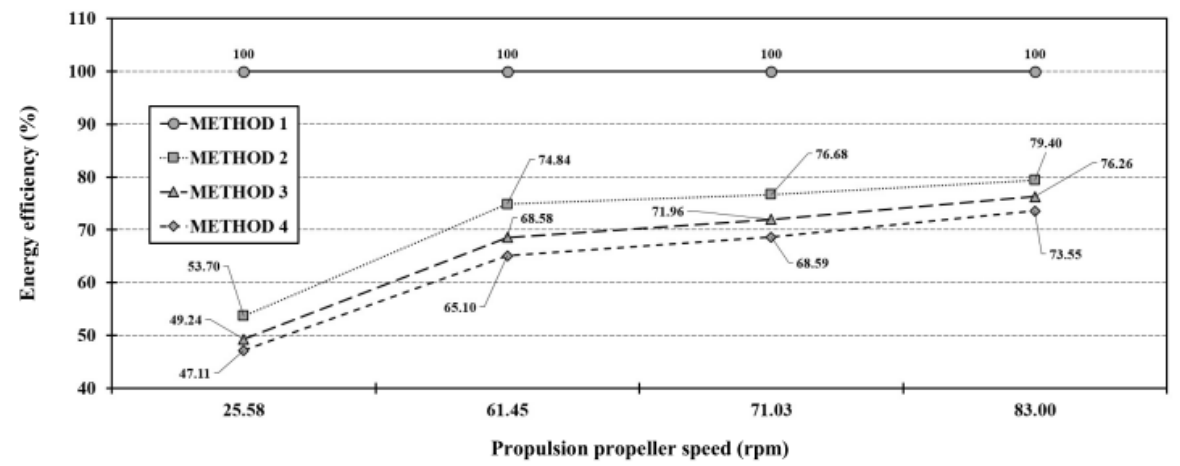

Figure 7 - Energy efficiency of the whole main marine steam turbine at each observed load by using all energy analysis methods

The final conclusions which can be highlighted in energy analysis of the main marine steam turbine as well as in energy analysis of any other steam turbine are that Method 1 did not result with a useful values without knowledge of additional losses, while the other presented methods can be used. Higher number of ideal (isentropic) steam expansion process divisions inside the same steam turbine will result with higher energy loss and simultaneously with a lower energy efficiency of the whole turbine at any observed load.

Exergy analysis results of the main marine steam turbine at all observed loads are presented in Figure 8. Similar as in the applicable energy analysis methods, exergy analysis shows that increase in main marine turbine load increases exergy destruction and simultaneously increases exergy efficiency of the whole turbine. At all observed main marine steam turbine loads, exergy destruction ranges between $608.64 \mathrm{~kW}$ and $5922.86 \mathrm{~kW}$, while the turbine exergy efficiency ranges between $54.94 \%$ and $80.73 \%$.

In comparison to applicable energy analysis methods, exergy analysis gives results which are (by obtained values) the closest to energy analysis Method 2. 


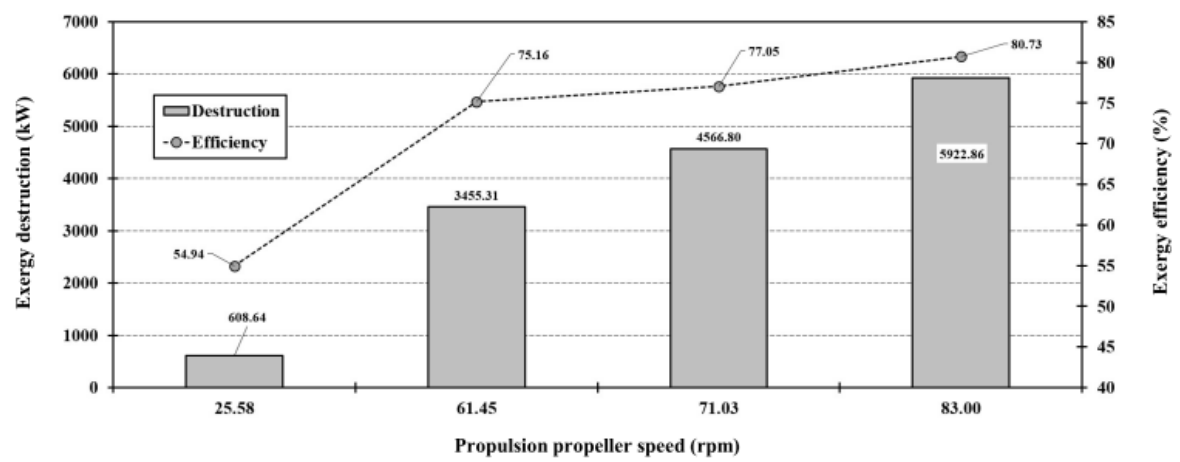

Figure 8 - Exergy destruction and exergy efficiency of the whole main marine steam turbine at each observed load

Further analysis of the main marine steam turbine will be based on the various artificial intelligence (AI) methods. So far, our research team proves that AI methods can be successfully implemented in the estimation of ship speed [98], in the condition-based maintenance of propulsion system components [99], in predicting of ship residuary resistance [100], in marine objects recognition [101] as well as in other non-marine applications [102-105]. Therefore, we believe that tracking of main marine steam turbine operating parameters by using AI methods can be successfully performed. Our second intention is to perform main marine steam turbine optimization (if possible), by using the same idea as in [106] where the route path optimization is obtained.

\section{Conclusions}

In this paper is presented energy and exergy analysis of the main marine steam turbine at four different loads. Energy analysis is performed by using four different methods. Performed analysis allows distinguishing advantages and disadvantages of all observed energy analysis methods and its comparison to exergy analysis of the same steam turbine. Observing main marine steam turbine at various loads also allows insight into the turbine operation during the load change, based on the measurement results obtained in exploitation conditions. The main conclusions of the performed research are:

Real (polytropic) power of the whole main marine steam turbine is the sum of real power produced by both turbine cylinders (HPC and LPC). At low loads, the dominant power producer is HPC, while at middle and high loads the role of dominant power producer is taken by LPC.

Presented energy analysis Method 1 which is based on the same principles as exergy analysis, will give energy losses equal to zero and energy efficiency equal to 
$100 \%$ for the analyzed as well as for any other steam turbine, at any load. Therefore, this method should be avoided if the majority of turbine losses are not known.

Energy analysis Methods 2, 3 and 4 can always be used in the research of any steam turbine. However, it should be highlighted that increase in ideal (isentropic) steam expansion process divisions will result with an increase in energy losses and with a decrease in energy efficiency of any steam turbine at any observed load.

Energy analysis Method 2 which consists of only one ideal (isentropic) steam expansion process, for the whole turbine at all observed loads, results with the lowest energy losses (in the range between $639.98 \mathrm{~kW}$ and $6434.17 \mathrm{~kW}$ ) as well as with the highest energy efficiency (in a range between $53.70 \%$ and $79.40 \%$ ) in comparison to other applicable energy analysis methods.

The results of the main turbine exergy analysis in terms of loss and efficiency, will be the closest (according to obtained values) to energy analysis Method 2. For the observed loads, whole main turbine exergy destruction is in range from 608.64 $\mathrm{kW}$ to $5922.86 \mathrm{~kW}$, while the exergy efficiency range of the whole turbine is between $54.94 \%$ and $80.73 \%$.

Exergy analysis and all three applicable energy analysis methods show that increase in the main turbine load results with simultaneous increase in turbine losses and efficiencies (both energy and exergy).

Further research, development and possible optimization of the analyzed main marine steam turbine will be performed by using various artificial intelligence methods.

\section{Acknowledgment}

This research has been supported by the Croatian Science Foundation under the project IP-2018-01-3739, CEEPUS network CIII-HR-0108, European Regional Development Fund under the grant KK.01.1.1.01.0009 (DATACROSS), project CEKOM under the grant KK.01.2.2.03.0004, CEI project "COVIDAi” (305.6019-20), University of Rijeka scientific grant uniri-tehnic-18-275-1447 and University of Rijeka scientific grant uniri-tehnic-18-18-1146.

\section{References}

1. Muše, A., Jurić, Z., Račić, N., \& Radica, G. (2020). Modelling, performance improvement and emission reduction of large two-stroke diesel engine using multi-zone combustion model. Journal of Thermal Analysis and Calorimetry, 1-14. (doi:10.1007/s10973-020-09321-7)

2. Feng, Y., Wang, H., Gao, R., \& Zhu, Y. (2019). A Zero-Dimensional Mixing Controlled Combustion Model for Real Time Performance Simulation of Marine Two-Stroke Diesel Engines. Energies, 12(10), 2000. (doi:10.3390/en12102000)

3. Mrzljak, V. (2015). Quasidimensional model for numerical simulations of marine two-stroke diesel engine (Doctoral dissertation, Tehnički fakultet, Sveučilište u Rijeci).

4. Ryu, Y., Lee, Y., \& Nam, J. (2016). Performance and emission characteristics of additives-enhanced heavy fuel oil in large two-stroke marine diesel engine. Fuel, 182, 850-856. (doi:10.1016/j. fuel.2016.06.029) 
5. Bukovac, O., Medica, V., \& Mrzljak, V. (2015). Steady state performances analysis of modern marine two-stroke low speed diesel engine using MLP neural network model. Brodogradnja: Teorija i praksa brodogradnje i pomorske tehnike, 66(4), 57-70.

6. Raptotasios, S. I., Sakellaridis, N. F., Papagiannakis, R. G., \& Hountalas, D. T. (2015). Application of a multi-zone combustion model to investigate the NOx reduction potential of two-stroke marine diesel engines using EGR. Applied Energy, 157, 814-823. (doi:10.1016/j.apenergy.2014.12.041)

7. He, Y., \& Rutland, C. J. (2002). Modeling of a turbocharged di diesel engine using artificial neural networks. SAE Transactions, 1532-1543.

8. Ramesh, N., \& Mallikarjuna, J. M. (2017). Low temperature combustion strategy in an offhighway diesel engine-experimental and CFD study. Applied Thermal Engineering, 124, 844-854. (doi:10.1016/j.applthermaleng.2017.06.078)

9. Mrzljak, V., Zarković, B., \& Poljak, I. (2017). Fuel mass flow variation in direct injection diesel engine-influence on the change of the main engine operating parameters. Pomorstvo, 31(2), 119127. (doi:10.31217/p.31.2.6)

10. Park, S., Kim, Y., Woo, S., \& Lee, K. (2017). Optimization and calibration strategy using design of experiment for a diesel engine. Applied Thermal Engineering, 123, 917-928. (doi:10.1016/j. applthermaleng.2017.05.171)

11. Huang, M., Gowdagiri, S., Cesari, X. M., \& Oehlschlaeger, M. A. (2016). Diesel engine CFD simulations: Influence of fuel variability on ignition delay. Fuel, 181, 170-177. (doi:10.1016/j. fuel.2016.04.137)

12. Mrzljak, V., Medica, V., \& Mrakovčić, T. (2015). Simulation of diesel engine cylinder process using quasi-dimensional numerical model. Pomorstvo, 29(2), 165-169.

13. Wang, G., Yu, W., Li, X., Su, Y., Yang, R., \& Wu, W. (2019). Experimental and numerical study on the influence of intake swirl on fuel spray and in-cylinder combustion characteristics on large bore diesel engine. Fuel, 237, 209-221. (doi:10.1016/j.fuel.2018.09.156)

14. Mrzljak, V., \& Žarković, B. (2019). Numerical Analysis of the Fuel Spray Packages Penetration and Gas Inflow from Quasi-Dimensional DI Diesel Engine Numerical Model. Zbornik Veleučilišta u Rijeci, 7(1), 335-357. (doi:10.31784/zvr.7.1.11)

15. Rajak, U., Nashine, P., Singh, T. S., \& Verma, T. N. (2018). Numerical investigation of performance, combustion and emission characteristics of various biofuels. Energy Conversion and Management, 156, 235-252. (doi:10.1016/j.enconman.2017.11.017)

16. Channapattana, S. V., Pawar, A. A., \& Kamble, P. G. (2017). Optimisation of operating parameters of DI-CI engine fueled with second generation Bio-fuel and development of ANN based prediction model. Applied energy, 187, 84-95. (doi:10.1016/j.apenergy.2016.11.030)

17. Lamas Galdo, M. I., Castro-Santos, L., \& Rodriguez Vidal, C. G. (2020). Numerical analysis of NOx reduction using ammonia injection and comparison with water injection. Journal of Marine Science and Engineering, 8(2), 109. (doi:10.3390/jmse8020109)

18. Senčić, T., Mrzljak, V., Blecich, P., \& Bonefačić, I. (2019). 2D CFD simulation of water injection strategies in a large marine engine. Journal of Marine Science and Engineering, 7(9), 296. (doi:10.3390/jmse7090296)

19. Sartomo, A., Santoso, B., \& Muraza, O. (2020). Recent progress on mixing technology for wateremulsion fuel: A review. Energy Conversion and Management, 213, 112817. (doi:10.1016/j. enconman.2020.112817)

20. Marques, C. H., Caprace, J. D., Belchior, C. R., \& Martini, A. (2019). An Approach for Predicting the Specific Fuel Consumption of Dual-Fuel Two-Stroke Marine Engines. Journal of Marine Science and Engineering, 7(2), 20. (doi:10.3390/jmse7020020)

21. Kocijel, L., Mrzljak, V., Čohodar Husić, M., \& Čekić, A. (2019). Numerical Analysis of Fuel Injector Nozzle Geometry-Influence on Liquid Fuel Contraction Coefficient and Reynolds Number. Pomorski zbornik, 57(1), 23-45. (doi:10.18048/2019.57.02)

22. Fernández, I. A., Gómez, M. R., Gómez, J. R., \& Insua, Á. B. (2017). Review of propulsion systems on LNG carriers. Renewable and Sustainable Energy Reviews, 67, 1395-1411. (doi:10.1016/j. rser.2016.09.095)

23. Ammar, N. R. (2019). Environmental and cost-effectiveness comparison of dual fuel propulsion options for emissions reduction onboard LNG carriers. Brodogradnja: Teorija i praksa brodogradnje i pomorske tehnike, 70(3), 61-77. (doi:10.21278/brod70304)

24. Ahn, J., Noh, Y., Park, S. H., Choi, B. I., \& Chang, D. (2017). Fuzzy-based failure mode and 
effect analysis (FMEA) of a hybrid molten carbonate fuel cell (MCFC) and gas turbine system for marine propulsion. Journal of Power Sources, 364, 226-233. (doi:10.1016/j.jpowsour.2017.08.028)

25. Budiyanto, M. A., \& Nawara, R. (2020). The optimization of exergoenvironmental factors in the combined gas turbine cycle and carbon dioxide cascade to generate power in LNG tanker ship. Energy Conversion and Management, 205, 112468. (doi:10.1016/j.enconman.2020.112468)

26. Raj, R., Ghandehariun, S., Kumar, A., Geng, J., \& Linwei, M. (2016). A techno-economic study of shipping LNG to the Asia-Pacific from Western Canada by LNG carrier. Journal of Natural Gas Science and Engineering, 34, 979-992. (doi:10.1016/j.jngse.2016.07.024)

27. Vanem, E., Antao, P., Østvik, I., \& de Comas, F. D. C. (2008). Analysing the risk of LNG carrier operations. Reliability Engineering \& System Safety, 93(9), 1328-1344. (doi:10.1016/j. ress.2007.07.007)

28. Jeong, B., Oguz, E., Wang, H., \& Zhou, P. (2018). Multi-criteria decision-making for marine propulsion: Hybrid, diesel electric and diesel mechanical systems from cost-environment-risk perspectives. Applied Energy, 230, 1065-1081. (doi:10.1016/j.apenergy.2018.09.074)

29. Jeong, B., Wang, H., Oguz, E., \& Zhou, P. (2018). An effective framework for life cycle and cost assessment for marine vessels aiming to select optimal propulsion systems. Journal of Cleaner Production, 187, 111-130. (doi:10.1016/j.jclepro.2018.03.184)

30. Chang, D., Rhee, T., Nam, K., Chang, K., Lee, D., \& Jeong, S. (2008). A study on availability and safety of new propulsion systems for LNG carriers. Reliability Engineering \& System Safety, 93(12), 1877-1885. (doi:10.1016/j.ress.2008.03.013)

31. Mrzljak, V., Poljak, I., \& Medica-Viola, V. (2017). Dual fuel consumption and efficiency of marine steam generators for the propulsion of LNG carrier. Applied Thermal Engineering, 119, 331-346. (doi:10.1016/j.applthermaleng.2017.03.078)

32. Koroglu, T., \& Sogut, O. S. (2018). Conventional and advanced exergy analyses of a marine steam power plant. Energy, 163, 392-403. (doi:10.1016/j.energy.2018.08.119)

33. Attah, E. E., \& Bucknall, R. (2015). An analysis of the energy efficiency of LNG ships powering options using the EEDI. Ocean Engineering, 110, 62-74. (doi:10.1016/j.oceaneng.2015.09.040)

34. Marques, C. H., Belchior, C. R. P., \& Caprace, J. D. (2019). An early-stage approach to optimise a marine energy system for liquefied natural gas carriers: Part A-Developed approach. Ocean Engineering, 181, 161-172. (doi:10.1016/j.oceaneng.2019.04.020)

35. Marques, C. H., Belchior, C. R. P., \& Caprace, J. D. (2019). An early-stage approach to optimise a marine energy system for liquefied natural gas carriers: Part B-Application. Ocean Engineering, 174, 96-107. (doi:10.1016/j.oceaneng.2019.01.045)

36. Ibrahim, T. K., Mohammed, M. K., Awad, O. I., Abdalla, A. N., Basrawi, F., Mohammed, M. N., ... \& Mamat, R. (2018). A comprehensive review on the exergy analysis of combined cycle power plants. Renewable and Sustainable Energy Reviews, 90, 835-850. (doi:10.1016/j.rser.2018.03.072)

37. Kaushik, S. C., Reddy, V. S., \& Tyagi, S. K. (2011). Energy and exergy analyses of thermal power plants: A review. Renewable and Sustainable energy reviews, 15(4), 1857-1872. (doi:10.1016/j. rser.2010.12.007)

38. Fadhil, A. N., Shihab, A. P. A. S., \& Faisal, S. H. (2017). Assessment of AL-Hartha Steam Power Station Using Energy and Exergy Analysis. International Journal of Modern Studies in Mechanical Engineering, 3(2), 17-30. (doi:10.20431/2454-9711.0302003)

39. Hafdhi, F., Khir, T., Yahyia, A. B., \& Brahim, A. B. (2015). Energetic and exergetic analysis of a steam turbine power plant in an existing phosphoric acid factory. Energy Conversion and Management, 106, 1230-1241. (doi:10.1016/j.enconman.2015.10.044)

40. Şöhret, Y., Açıkkalp, E., Hepbasli, A., \& Karakoc, T. H. (2015). Advanced exergy analysis of an aircraft gas turbine engine: splitting exergy destructions into parts. Energy, 90, 1219-1228. (doi:10.1016/j.energy.2015.06.071)

41. Mrzljak, V., Poljak, I., \& Mrakovčić, T. (2017). Energy and exergy analysis of the turbo-generators and steam turbine for the main feed water pump drive on LNG carrier. Energy conversion and management, 140, 307-323. (doi:10.1016/j.enconman.2017.03.007)

42. Mrzljak, V., Poljak, I., \& Medica-Viola, V. (2017). Thermodynamical analysis of high-pressure feed water heater in steam propulsion system during exploitation. Brodogradnja: Teorija i praksa brodogradnje i pomorske tehnike, 68(2), 45-61. (doi:10.21278/brod68204)

43. Çiçek, A. N. (2009). Exergy analysis of a crude oil carrier steam plant. MSc. Thesis (in Turkish), Istanbul, Istanbul Technical University. 
44. Mrzljak, V., Prpić-Oršić, J., \& Senčić, T. (2018). Change in steam generators main and auxiliary energy flow streams during the load increase of LNG carrier steam propulsion system. Pomorstvo, 32(1), 121-131. (doi:10.31217/p.32.1.15)

45. Taylor, D. A. (1998). Introduction to Marine Engineering. Elsevier Butterworth-Heinemann.

46. Mrzljak, V., Poljak, I., \& Medica-Viola, V. (2016). Efficiency and losses analysis of low-pressure feed water heater in steam propulsion system during ship maneuvering period. Pomorstvo, 30(2), 133-140. (doi:10.31217/p.30.2.6)

47. Malin, M. R. (1997). Modelling flow in an experimental marine condenser. International communications in heat and mass transfer, 24(5), 597-608. (doi:10.1016/S0735-1933(97)00046-8)

48. Škopac, L., Medica-Viola, V., \& Mrzljak, V. (2020). Selection Maps of Explicit Colebrook Approximations according to Calculation Time and Precision. Heat Transfer Engineering, 1-15. (doi:10.1080/01457632.2020.1744248)

49. Johnson, C. M., Vanderplaats, G. N., \& Marto, P. J. (1980). Marine condenser design using numerical optimization. ASME.

50. Medica-Viola, V., Pavković, B., \& Mrzljak, V. (2018). Numerical model for on-condition monitoring of condenser in coal-fired power plants. International Journal of Heat and Mass Transfer, 117, 912-923. (doi:10.1016/j.ijheatmasstransfer.2017.10.047)

51. Laskowski, R. (2016). Relations for steam power plant condenser performance in off-design conditions in the function of inlet parameters and those relevant in reference conditions. Applied Thermal Engineering, 103, 528-536. (doi:10.1016/j.applthermaleng.2016.04.127)

52. Mrzljak, V., Poljak, I., \& Žarković, B. (2018). Exergy analysis of steam pressure reduction valve in marine propulsion plant on conventional LNG carrier. NAŠE MORE: znanstveno-stručni časopis za more i pomorstvo, 65(1), 24-31. (doi:10.17818/NM/2018/1.4)

53. Lisowski, E., \& Rajda, J. (2013). CFD analysis of pressure loss during flow by hydraulic directional control valve constructed from logic valves. Energy Conversion and Management, 65, 285-291. (doi:10.1016/j.enconman.2012.08.015)

54. McBirnie, S. C. (2013). Marine, Steam Engines, and Turbines. Elsevier.

55. Tanuma, T. (Ed.). (2017). Advances in Steam Turbines for Modern Power Plants. Woodhead Publishing.

56. Schirrmacher, S., Overmeyer, L., \& Lorisch, S. (2016). Wireless condition monitoring of a marine gearbox. Ship Technology Research, 63(1), 38-49. (doi:10.1080/09377255.2015.1137427)

57. Carlton, J. (2018). Marine propellers and propulsion. Butterworth-Heinemann.

58. Behrendt, C., \& Stoyanov, R. (2018). Operational Characteristic of Selected Marine Turbounits Powered by Steam from Auxiliary Oil-Fired Boilers. New Trends in Production Engineering, 1(1), 495-501. (doi:10.2478/ntpe-2018-0061)

59. Mrzljak, V., Prpić-Oršić, J., \& Poljak, I. (2018). Energy Power Losses and Efficiency of Low Power Steam Turbine for the Main Feed Water Pump Drive in the Marine Steam Propulsion System. Pomorski zbornik, 54(1), 37-51. (doi:10.18048/2018.54.03)

60. Mrzljak, V. (2018). Low power steam turbine energy efficiency and losses during the developed power variation. Tehnički glasnik, 12(3), 174-180. (doi:10.31803/tg-20180201002943)

61. Kanoğlu, M., Çengel, Y. A., \& Dinçer, İ. (2012). Efficiency evaluation of energy systems. Springer Science \& Business Media.

62. Baldi, F., Johnson, H., Gabrielii, C., \& Andersson, K. (2014). Energy and exergy analysis of ship energy systems-the case study of a chemical tanker. In 27th ECOS, International Conference on Efficiency, Cost, Optimization, Simulation and Environmental Impact of Energy Systems.

63. Noroozian, A., Mohammadi, A., Bidi, M., \& Ahmadi, M. H. (2017). Energy, exergy and economic analyses of a novel system to recover waste heat and water in steam power plants. Energy conversion and management, 144, 351-360. (doi:10.1016/j.enconman.2017.04.067)

64. Taheri, M. H., Mosaffa, A. H., \& Farshi, L. G. (2017). Energy, exergy and economic assessments of a novel integrated biomass based multigeneration energy system with hydrogen production and LNG regasification cycle. Energy, 125, 162-177. (doi:10.1016/j.energy.2017.02.124)

65. Ahmadi, G. R., \& Toghraie, D. (2016). Energy and exergy analysis of Montazeri steam power plant in Iran. Renewable and Sustainable Energy Reviews, 56, 454-463. (doi:10.1016/j.rser.2015.11.074)

66. Mrzljak, V., \& Poljak, I. (2019). Energy Analysis of Main Propulsion Steam Turbine from Conventional LNG Carrier at Three Different Loads. NAŠE MORE: znanstveno-stručni časopis za more i pomorstvo, 66(1), 10-18. (doi:10.17818/NM/2019/1.2) 
67. Baldi, F., Ahlgren, F., Nguyen, T. V., Thern, M., \& Andersson, K. (2018). Energy and exergy analysis of a cruise ship. Energies, 11(10), 2508. (doi:10.3390/en11102508)

68. Kocijel, L., Poljak, I., Mrzljak, V., \& Car, Z. (2020). Energy Loss Analysis at the Gland Seals of a Marine Turbo-Generator Steam Turbine. Tehnički glasnik, 14(1), 19-26. (doi:10.31803/tg20191031094436)

69. Elhelw, M., Al Dahma, K. S., \& el Hamid Attia, A. (2019). Utilizing exergy analysis in studying the performance of steam power plant at two different operation mode. Applied Thermal Engineering, 150, 285-293. (doi:10.1016/j.applthermaleng.2019.01.003)

70. Szargut, J. (2005). Exergy method: technical and ecological applications (Vol. 18). WIT press.

71. Mrzljak, V., Blecich, P., Anđelić, N., \& Lorencin, I. (2019). Energy and Exergy Analyses of Forced Draft Fan for Marine Steam Propulsion System during Load Change. Journal of Marine Science and Engineering, 7(11), 381. (doi:10.3390/jmse7110381)

72. Eboh, F. C., Ahlström, P., \& Richards, T. (2017). Exergy analysis of solid fuel-fired heat and power plants: a review. Energies, 10(2), 165. (doi:10.3390/en10020165)

73. Medica-Viola, V., Mrzljak, V., Anđelić, N., \& Jelić, M. (2020). Analysis of Low-Power Steam Turbine With One Extraction for Marine Applications. NAŠE MORE: znanstveni časopis za more i pomorstvo, 67(2), 87-95. (doi:10.17818/NM/2020/2.1)

74. Ameri, M., Mokhtari, H., \& Sani, M. M. (2018). 4E analyses and multi-objective optimization of different fuels application for a large combined cycle power plant. Energy, 156, 371-386. (doi:10.1016/j.energy.2018.05.039)

75. Kumar, V., Pandya, B., \& Matawala, V. (2019). Thermodynamic studies and parametric effects on exergetic performance of a steam power plant. International Journal of Ambient Energy, 40(1), 1-11. (doi:10.1080/01430750.2017.1354326)

76. Lorencin, I., Anđelić, N., Mrzljak, V., \& Car, Z. (2019). Exergy analysis of marine steam turbine labyrinth (gland) seals. Pomorstvo, 33(1), 76-83. (doi:10.31217/p.33.1.8)

77. Tan, H., Shan, S., Nie, Y., \& Zhao, Q. (2018). A new boil-off gas re-liquefaction system for LNG carriers based on dual mixed refrigerant cycle. Cryogenics, 92, 84-92. (doi:10.1016/j. cryogenics.2018.04.009)

78. Aljundi, I. H. (2009). Energy and exergy analysis of a steam power plant in Jordan. Applied thermal engineering, 29(2-3), 324-328. (doi:10.1016/j.applthermaleng.2008.02.029)

79. Dincer, I., \& Rosen, M. A. (2012). Exergy: energy, environment and sustainable development. Newnes.

80. Mrzljak, V., Senčić, T., \& Žarković, B. (2018). Turbogenerator steam turbine variation in developed power: Analysis of exergy efficiency and exergy destruction change. Modelling and Simulation in Engineering, 2018. (doi:10.1155/2018/2945325)

81. Ogorure, O. J., Oko, C. O. C., Diemuodeke, E. O., \& Owebor, K. (2018). Energy, exergy, environmental and economic analysis of an agricultural waste-to-energy integrated multigeneration thermal power plant. Energy conversion and management, 171, 222-240. (doi:10.1016/j. enconman.2018.05.093)

82. Sutton, I. (2017). Plant design and operations. Gulf Professional Publishing.

83. Moran, M. J., Shapiro, H. N., Boettner, D. D., \& Bailey, M. B. (2010). Fundamentals of engineering thermodynamics. John Wiley \& Sons.

84. Mrzljak, V., Poljak, I., \& Prpić-Oršić, J. (2019). Exergy analysis of the main propulsion steam turbine from marine propulsion plant. Brodogradnja: Teorija i praksa brodogradnje i pomorske tehnike, 70(1), 59-77. (doi:10.21278/brod70105)

85. Cangel, Y. A., \& Boles, M. A. (2002). Thermodynamics: An Engineering Approach 4th Edition in SI Units. Singapore (SI): McGraw-Hill.

86. Zhao, Z., Su, S., Si, N., Hu, S., Wang, Y., Xu, J., ... \& Xiang, J. (2017). Exergy analysis of the turbine system in a $1000 \mathrm{MW}$ double reheat ultra-supercritical power plant. Energy, 119, 540-548. (doi:10.1016/j.energy.2016.12.072)

87. Uysal, C., Kurt, H., \& Kwak, H. Y. (2017). Exergetic and thermoeconomic analyses of a coalfired power plant. International Journal of Thermal Sciences, 117, 106-120. (doi:10.1016/j. ijthermalsci.2017.03.010)

88. Erdem, H. H., Akkaya, A. V., Cetin, B., Dagdas, A., Sevilgen, S. H., Sahin, B., ... \& Atas, S. (2009). Comparative energetic and exergetic performance analyses for coal-fired thermal power plants in Turkey. International Journal of Thermal Sciences, 48(11), 2179-2186. (doi:10.1016/j. 
ijthermalsci.2009.03.007)

89. Adibhatla, S., \& Kaushik, S. C. (2014). Energy and exergy analysis of a super critical thermal power plant at various load conditions under constant and pure sliding pressure operation. Applied thermal engineering, 73(1), 51-65. (doi:10.1016/j.applthermaleng.2014.07.030)

90. Mrzljak, V., Poljak, I., \& Medica-Viola, V. (2017). Energy and exergy efficiency analysis of sealing steam condenser in propulsion system of LNG carrier. NAŠE MORE: znanstveno-stručni časopis za more i pomorstvo, 64(1), 20-25. (doi:10.17818/NM/2017/1.4)

91. Ray, T. K., Datta, A., Gupta, A., \& Ganguly, R. (2010). Exergy-based performance analysis for proper O\&M decisions in a steam power plant. Energy Conversion and Management, 51(6), 1333-1344. (doi:10.1016/j.enconman.2010.01.012)

92. Blažević, S., Mrzljak, V., Anđelić, N., \& Car, Z. (2019). Comparison of energy flow stream and isentropic method for steam turbine energy analysis. Acta Polytechnica, 59(2), 109-125. (doi:10.14311/AP.2019.59.0109)

93. http://www.krtproduct.com (accessed: 17.06.2020.)

94. http://www.industriascontrolpro.com (accessed: 17.06.2020.)

95. https://www.greisinger.de (accessed: 18.06.2020.)

96. https://www.kyma.no (accessed: 19.06.2020.)

97. Lemmon, E. W., Huber, M. L., \& McLinden, M. O. (2010). NIST Standard Reference Database 23, Reference Fluid Thermodynamic and Transport Properties (REFPROP), version 9.0, National Institute of Standards and Technology. R1234yf. fld file dated December, 22, 2010.

98. Baressi Šegota, S., Lorencin, I., Musulin, J., Štifanić, D., \& Car, Z. (2020). Frigate Speed Estimation Using CODLAG Propulsion System Parameters and Multilayer Perceptron. NAŠE MORE: znanstveni časopis za more i pomorstvo, 67(2), 117-125. (doi:10.17818/NM/2020/2.4)

99. Lorencin, I., Anđelić, N., Mrzljak, V., \& Car, Z. (2019). Multilayer Perceptron approach to Condition-Based Maintenance of Marine CODLAG Propulsion System Components. Pomorstvo, 33(2), 181-190. (doi:10.31217/p.33.2.8)

100. Baressi Šegota, S., Anđelić, N., Kudláček, J., \& Čep, R. (2019). Artificial neural network for predicting values of residuary resistance per unit weight of displacement. Pomorski zbornik, 57(1), 9-22. (doi:10.18048/2019.57.01)

101. Lorencin, I., Anđelić, N., Mrzljak, V., \& Car, Z. (2019). Marine Objects Recognition Using Convolutional Neural Networks. NAŠE MORE: znanstveno-stručni časopis za more i pomorstvo, 66(3), 112-119. (doi:10.17818/NM/2019/3.3)

102. Štifanić, D., Musulin, J., Miočević, A., Baressi Šegota, S., Šubić, R., \& Car, Z. (2020). Impact of COVID-19 on Forecasting Stock Prices: An Integration of Stationary Wavelet Transform and Bidirectional Long Short-Term Memory. Complexity, 2020. (doi:10.1155/2020/1846926)

103. Lorencin, I., Anđelić, N., Mrzljak, V., \& Car, Z. (2019). Genetic Algorithm Approach to Design of Multi-Layer Perceptron for Combined Cycle Power Plant Electrical Power Output Estimation. Energies, 12(22), 4352. (doi:10.3390/en12224352)

104. Car, Z., Baressi Segota, S., Anđelić, N., Lorencin, I., \& Mrzljak, V. (2020). Modeling the Spread of COVID-19 Infection Using a Multilayer Perceptron. Computational and Mathematical Methods in Medicine, 2020. (doi:10.1155/2020/5714714)

105. Lorencin, I., Anđelić, N., Španjol, J., \& Car, Z. (2020). Using multi-layer perceptron with Laplacian edge detector for bladder cancer diagnosis. Artificial Intelligence in Medicine, 102, 101746. (doi:10.1016/j.artmed.2019.101746)

106. Baressi Šegota, S., Lorencin, I., Ohkura, K., \& Car, Z. (2019). On the Traveling Salesman Problem in Nautical Environments: an Evolutionary Computing Approach to Optimization of Tourist Route Paths in Medulin, Croatia. Pomorski zbornik, 57(1), 71-87. (doi:10.18048/2019.57.05) 